\title{
FACTORS AFFECTING THE DURIAN PRODUCTION OF FARMERS IN THE EASTERN REGION OF THAILAND
}

\author{
aSupat Thongkaew, bChalermpon Jatuporn*, cPatana Sukprasert, bPaisan Rueangrit, dSiros Tongchure \\ a Crop Integration Business, Charoen Pokphand Group, Thailand. \\ ${ }^{b}$ School of Economics, Sukhothai Thammathirat Open University, Thailand. \\ ${ }^{c}$ Faculty of Agriculture, Kasetsart University, Thailand. \\ ${ }^{d}$ Faculty of Agriculture and Life Sciences, Chandrakasem Rajabhat University, Thailand.
}

\section{ART ICLE IN F O}

\section{Article History}

Received: April 23, 2021

Revised: June 26, 2021

Accepted: August 25, 2021

\section{Keywords}

Monthong Durian

Tropical Fruit

Agricultural Policy

Productivity

\section{A B S T R A C T}

Thailand is the largest durian producer and exporter in the world market. In addition, durian is the most important fruit crop in Thailand because it can generate a higher income from exports with a value of approximately 45,349-million-baht, equivalent to an export quantity of 653,564 tons in 2019 . The objective is to analyze the factors affecting the durian production of farmers in the eastern region of Thailand, namely Chanthaburi, Rayong, and Trad Provinces. The sample of 395 durian farmers underwent observation using simple random sampling via the questionnaire approach. The statistics consisted of mean, percentage, and multiple regression. The findings revealed that the positive factors affecting the durian production of farmers in the eastern region of Thailand are the experience of the farmers in growing durian, the size of the workforce, the planted area of durian, the number of durian trees, and the number of durian trees per planted area, while the negative factors affecting the durian production of farmers in the eastern region of Thailand are the age of the farmers and the cultivation of organic durian. The results will be beneficial to farmers, government, and related stakeholders, who can further apply these findings to enhance the efficiency of durian production to be the quality durian for domestic and foreign consumers.

Corresponding Author: Chalermpon Jatuporn

Email: Chalermpon.Jat@stou.ac.th

(C) The Author(s) 2021.

\section{INTRODUCTION}

Fruit is an important agricultural product in Thailand. Since the country has a tropical climate, there are various high-quality fruits grown throughout the year, making Thai fruit very popular on both the domestic and international markets. Generally, fruit is an economic crop that has a higher value than rice farming and other field crops such as cassava, sugarcane, maize, etc. In addition, Thailand has a suitable area for cultivating tropical fruits, which are famous such as durian, longan, mangosteen, and rambutan for both domestic and international markets. Therefore, Thailand can export a lot of fruit and generate revenue for the country and domestic farmers. In 2019, Thailand's exports as a whole were worth 113,118 million baht; fresh fruit exports were worth 90,310 million baht or 79.84\% (Ministry of Commerce, 2020a). Nowadays, the fruit consumption demand is predicted to rise due to the higher population, as well as behavioral changes in consumption resulting from higher incomes that lead people to consume fruit, which is not the main course, more than before. Durian, a tropical fruit, has its origin from Borneo Island, Brunei, 
Malaysia, and Indonesia. In Thailand, durian spread out to the southern part of Thailand from Malaysia in 1687 (Somsri, 2008). In many countries, durian was called the "King of Fruit" because of its excellent flavor, surprising smell, and marketing power. Today, Thailand is the biggest durian producer and exporter in the world. Thailand has the potential to export durian to the world market the most, more than $95 \%$ of the global export volume, followed by Malaysia (4\%) and the others $(<1 \%)$ (Durian Harvests, 2021). The durian season starts in March every year and ends in September. According to the records in 2019, 143,455 farming households planted durian on 937,607 rai (6.25 rai $=1$ hectare). The outcome was up to $1,017,097$ tons, 270,441 tons for domestic consumption, and 653,564 tons for international exports which were worth 45,349 million baht. Of these exports, $97.85 \%$ of fresh durian was exported to three countries: China, Vietnam, and Hong Kong. The majority was exported to China at 375,202 tons or 26,332 million baht, followed by Vietnam with 164,380 tons or 11,090 million baht, and Hong Kong at 99,932 tons or 6,990 million baht. Moreover, durian was transformed to make it easier to export; 25,987 tons of durian were transformed into a frozen product worth 5,371 million baht, 1,211 tons of durian were transformed to durian paste worth 132 million baht, and 215 tons of durian to freeze-dried durian worth 200 million baht. These products were exported to different countries: China, the United States, Russia, and Australia (Office of Agricultural Economics, 2020a, 2020c; Ministry of Commerce, 2020b). The main competitors are Vietnam and Malaysia since Vietnam has planted more and more durian every year, especially the Monthong type, which is the same species as Thailand. Even though Vietnamese Monthong durian has lower quality than the Thai species, Vietnam is now improving the previous species. On the other hand, Malaysia has started to negotiate with the Chinese government about fresh durian exports apart from frozen products. Therefore, the production of durian for export from these competing countries may cause Thailand to lose market share. In addition, this may affect the price and cause production volatility, although both current demands for durian and durian prices are likely to increase.

Most of the durian growing areas of Thailand are in the eastern and southern regions. The durian season in the eastern region each year starts from April to June, accounting for almost half of the country's production throughout the year. While the durian season for the southern regions each year is from July to September, it accounts for $42 \%$ of the country's production throughout the year. Hence, the eastern part of Thailand is the main cultivated area in Thailand, especially Chanthaburi, Rayong, and Trad Provinces which are mountainous and forested. The central part has mountainous plains, and the lower part has a river basin and coastal plain. The climate of the upper part of this region, Rayong Province, is a tropical savanna climate (Aw) and the lower part of this region, Chanthaburi Province, has a tropical monsoon climate (Am) with heavy rainfall. Within this region, Trad Province has the highest rainfall. In 2019, fruits that were significantly important to this region were durian, longan, mangosteen, and rambutan, with cultivated areas of 339,362 rai, 217,579 rai, 198,833 rai, and 113,004 rai, respectively. Planting durian in this region were 36,982 farmers on a cultivation area of 281,330 rai to gain 495,643 tons of durian. In this region, durian sales start in April and end in July every year. Over $50 \%$ of durian will be sold on the market in April and end in June. The famous durian species on the market are Monthong, Chanee, Kradum, and Puangmanee. The factors that influence consumers' decisions to buy durian in the eastern part of Thailand are consumer income, size of durian, consumers' satisfaction with the durian price, and the willingness of consumers to pay more for quality durian (Thongkaew et al., 2017). In addition, the factors that influence entrepreneurs' decisions to buy durian for export include the age of entrepreneurs, methods of business operation, and entrepreneurs' satisfaction in terms of price and distribution channels (Thongkaew, 2018). These are the reasons for the study of factors that affect durian production in the eastern region of Thailand to provide farmers with the fundamental knowledge to improve durian production and respond to the domestic and international market demands effectively.

Over the past ten years, the demand for durian has been steadily increased following the reports of the Office of Agricultural Economics (2020c, 2020b) and the findings of Rueangrit et al. (2020). As a result, the durian price rose in line with the supply and demand mechanism; therefore, it was an incentive for domestic farmers to start growing durian in various areas across the country. This study will be particularly useful for durian farmers 
to be used as a guideline for the most efficient durian production, which will benefit exporters to obtain quality durian and meet the needs of the trading partners. The purpose of this study is to analyze the factors affecting durian production in the eastern region of Thailand as it is the most important durian growing area in the country due to the production efficiency both in quantity and quality of the durian fruits at a high level by comparing to other domestic and foreign production areas.

The results of this study will be the practical guidelines to farmers for producing quality durian in other production regions, that now farmers in Thailand have popularly grown durian throughout the country. In addition, the government and agricultural extension agencies can be used as information to create training course programs to support the durian production of farmers in the country as well as to prepare for further policy implications to enhance the efficiency of durian production in Thailand.

\section{LITERATURE REVIEW}

After all this time, many farmers are very interested in planting durian since durian can bring a high income and respond to consumer demand in the domestic and international markets. However, they still face problems in the production process. (1) Farmer problems: they still use the old techniques to produce durian, which requires a higher capital cost than competitors, they collect the product before the harvesting season, and they have no bargaining power to negotiate with agents and exporters. (2) Management problems: disease damage as a result of planting in the same cultivated area, residue, and ethephon problems. Even though ethephon can rapidly ripen green durian by up to 60 $70 \%$, the flavor is terrible. If these durians are exported to other countries, they can ruin the image of Thai durian quality. Another consideration is climate changes with increased temperatures and average annual rainfall but decreased relative humidity, while the number of rainy days also tends to decrease (Angyurekul and Soratana, 2014; Worakuldumrongchai, 2015). Furthermore, the traders who sell durian from country to country, mostly Chinese people, have indicated the highest price to buy durian or low quality of durian to export; low quality of durian mixed with green durian, or claiming market restrictions instead of tax as an excuse; sanitation, pesticides and residues, and other factors that were out of control such as disease. This can lead to rejection by trading partners in other countries and can also affect the farmers.

The study of factors that affect agricultural production reveals many studies, such as the work of DATEPUMEE et al. (2019), who analyzed factors that affect potential durian exports in Chanthaburi Province by using questionnaires to observe 393 farmers via the logit model for analysis. As a result, they found that the main factors were soil types, fundamental knowledge, fruit ripening experiments, chemical use to prevent diseases and pests, pruning, and using fertilizer. Hassan et al. (2010) studied a similar topic with wheat in a mixed cropping zone of Punjab in India by observing 200 wheat growers. As a result, the factors that positively affected wheat yield in the mixed cropping zone of Punjab were seed rate, fertilizers, weeding cost, rotavator, and farmer education level. On the other hand, the sowing period was a negative factor affecting wheat productivity. The study of Promchon et al. (2018) found that factors influencing table grape production in Thailand were income, labor, cultivated area, and water sufficiency to plant table grapes throughout the year by observing 89 farmers using multiple regression analysis. Suriya et al. (2017) performed a similar study with the bananas of Nong Suea district, Pathum Thani Province, by taking 212 farmers based on multiple regression analysis. According to the results, the factors that affected banana production were labor, total income, other income apart from planting bananas, capital, and fundamental knowledge. Furthermore, Tun and Kang (2015) found that farm mechanical tools were a significant factor in enhancing the efficiency of rice production in Myanmar using the data envelopment analysis and the stochastic frontier approach. Zhang et al. (2020) studied the production function in corn yields in Daqing City, China, using the Cobb-Douglas concept. The findings of this study showed that the rates of using fertilizer and pesticide, effective precipitation, and planted area of corn had a positive relationship in increasing corn yield. Zulu et al. (2019) analyzed sugarcane production by small-scale growers in Ndwedwe Local Municipality, South Africa, using ordinary least squares (OLS) based on the Cobb-Douglas function. This study found that the quantity of labor and amount of chemicals applied had statistical significance and positively correlated with sugarcane production. In recent studies of Guntukula and Goyari (2020), Pipitpukdee et al. (2020), Sarkar et 
al. (2020), and Shayanmehr et al. (2020) focused on the impact of climatic and non-climatic factors on the productivity of agricultural commodities using the panel data analysis. The findings from these empirical studies confirmed that climatic factors could be one of the most important factors in the efficiency of agricultural production. For example, Sarkar et al. (2020) analyzed the impact of climate change on oil palm productivity in Malaysia using multiple regression analysis. The results found that changes in annual average temperature, planted areas, and sea-level rise were associated with the efficiency of oil palm production in Malaysia.

\section{MATERIALS AND METHODS}

The eastern region of Thailand consists of seven provinces in Table 1 classified by the Office of the Royal Society of Thailand, namely, Chanthaburi, Rayong, Trad, Prachin Buri, Nakhon Nayok, Chon Buri, and Sa Kaeo. The study area includes three provinces such as Chanthaburi, Rayong, Trad, covering almost all durian production in the eastern region. The population is
31,012 farmers who mainly grow durian in the eastern region of Thailand, in the provinces of Chanthaburi, Rayong, and Trad (Department of Agricultural Extension, 2016).

By using the formula of Yamane (1973) to find the sample size, it is determined that 395 farmers would be sufficient, and by using the quota selection method calculated from the ratio of farmers from each province, this gives the result of 267 farmers from Chanthaburi Province, 78 farmers from Rayong Province, and 50 farmers from Trad Province (Thongkaew, 2018). From the data above, this study used convenience sampling for observed samples, which included open-ended and closed-ended questions.

Five professionals were invited to check the content validity in order to correct and improve the questionnaires, and then trial tests were used with 30 durian farmers in Srisaket Province so that the reliability could be calculated using Cronbach's alpha coefficient, giving a result of 0.934 , proving that it is in a high confidence range.

Table 1. Harvested area, production, and yield of durian in the eastern region of Thailand.

\begin{tabular}{lcccccc}
\hline \multirow{2}{*}{ Production area } & \multicolumn{2}{c}{ Harvested area (rai) } & \multicolumn{2}{c}{ Production (ton) } & \multicolumn{2}{c}{ Yield (kg/rai) } \\
\cline { 2 - 7 } & 2018 & 2019 & 2018 & 2019 & 2018 & 2019 \\
\hline - Chanthaburi & 181,960 & 190,728 & 279,075 & 339,292 & $1,533.716$ & $1,778.931$ \\
- Rayong & 61,005 & 64,469 & 85,880 & 108,093 & $1,407.753$ & $1,676.666$ \\
- Trad & 24,187 & 26,133 & 38,951 & 48,158 & $1,610.411$ & $1,842.804$ \\
- Prachin Buri & 1,243 & 1,569 & 1,047 & 1,623 & 842.317 & $1,034.417$ \\
- Nakhon Nayok & 347 & 449 & 334 & 455 & 962.536 & $1,013.363$ \\
- Chon Buri & 142 & 231 & 141 & 230 & 992.957 & 995.671 \\
- Sa Kaeo & 0 & 0 & 0 & 0 & 0 & 0 \\
Eastern region & 268,884 & 283,579 & 405,428 & 497,851 & $7,349.691$ & $8,341.853$ \\
Whole Kingdom & 676,249 & 724,730 & 759,828 & $1,017,097$ & $1,123.593$ & $1,403.415$ \\
\hline
\end{tabular}

Source: Office of Agricultural Economics (2020c)

To analyze the samples, descriptive and inferential statistics are employed, such as percentage, mean, and multiple regression, which is used for analyzing the factors that affect the durian production of farmers in the eastern region of Thailand using the production function, which can be presented in the form of equation (1) below;

$\mathrm{Q}_{\mathrm{i}}=\mathrm{f}\left(\mathrm{X}_{1}, \mathrm{X}_{2}, \mathrm{X}_{3}, \ldots, \mathrm{X}_{12}\right)$

$Q_{i}=\alpha_{0}+\beta_{1} X_{1}+\beta_{2} X_{2}+\beta_{3} X_{3}+\ldots+\beta_{12} X_{12}+\varepsilon_{i}$

where $Q$ is the production of durian (unit: metric tons), $\mathrm{f}($.$) is the production function, \alpha$ is the constant, $\beta$ is the coefficient of the variables, $\varepsilon$ is the error, $X_{1}$ is the gender where 1 means male and 0 means female, $X_{2}$ is the age of farmers (unit: years), $X_{3}$ is the experience of farmers in growing durian (unit: years), $\mathrm{X}_{4}$ is the size of the workforce (unit: persons), $\mathrm{X}_{5}$ is the durian growing pattern where 1 means an integrated farming system and 0 is only growing durian, $\mathrm{X}_{6}$ is the GAP standard where 1 means farmers have the GAP standard and 0 means farmers do not have the GAP standard, $\mathrm{X}_{7}$ is the 
water resources for growing durian where 1 means farmers have sufficient water for growing durian and 0 means farmers have insufficient water for growing durian, $\mathrm{X}_{8}$ is the growing organic durian where 1 means farmers are growing organic durian and 0 means farmers are not growing organic durian, $\mathrm{X}_{9}$ is the planted area of durian (unit: rai), $X_{10}$ is the number of durian trees (unit: durian trees), $\mathrm{X}_{11}$ is the number of durian trees per planted area (unit: durian trees/rai), and $\mathrm{X}_{12}$ is the age of durian trees (unit: years).

The multiple regression analysis is considered using equation (1) by applying the Ordinary Least Squares (OLS) estimator to detect the size impact of the variables. To prevent the analysis results from being insufficiently reliable, this study will accompany the test of variance inflation factors (VIF) for checking the multicollinearity problem between the independent variables.

Next, the heteroskedasticity problem will diagnose using the Breusch-Pagan LM tests. Before explaining the relationships between the variables, any problems that may arise from the use of the OLS estimator must be addressed.

\section{RESULTS AND DISCUSSION}

The basic information about durian farmers reveals that $61.77 \%$ of farmers are male with an average age of 49.89 years, mostly graduated from secondary school, and having experience in the production of durian of 19.98 years. The farmers have around 3.77 persons in their households and have 19.64 rai of the planted area, which includes durian planted on up to 15.48 rai. The workforce in durian production is approximately 2.61 persons. They mostly have their own source of funds at $66.76 \%$. On the other hand, the farmers who are in debt have typically borrowed around 292,483.87 baht/household. The observed farmers have production costs of around 14,584.84 baht per rai with an income of approximately $94,133.64$ baht per rai, while average durian production is 1,321.21 kilograms per rai.

Table 2. Factors affecting the durian production of farmers in the eastern region of Thailand.

\begin{tabular}{lccccc}
\hline Variable & Coefficient & S.E. & t-ratio & p-value & VIF \\
\hline Constant & -135.327 & 28.308 & -4.780 & $<0.001$ & - \\
$\mathrm{X}_{1}$ & -3.742 & 2.599 & -1.440 & 0.150 & 1.050 \\
$\mathrm{X}_{2}$ & -0.479 & 0.205 & -2.329 & 0.020 & 1.913 \\
$\mathrm{X}_{3}$ & 0.466 & 0.250 & 1.861 & 0.063 & 2.552 \\
$\mathrm{X}_{4}$ & 4.903 & 2.276 & 2.154 & 0.031 & 1.866 \\
$\mathrm{X}_{5}$ & -0.040 & 3.416 & -0.011 & 0.990 & 1.113 \\
$\mathrm{X}_{6}$ & 0.106 & 3.384 & 0.031 & 0.974 & 1.138 \\
$\mathrm{X}_{7}$ & -3.341 & 3.461 & -0.965 & 0.335 & 1.050 \\
$\mathrm{X}_{8}$ & -6.151 & 2.939 & -2.093 & 0.037 & 1.118 \\
$\mathrm{X}_{9}$ & 11.736 & 1.535 & 7.641 & $<0.001$ & 7.552 \\
$\mathrm{X}_{10}$ & 0.376 & 0.086 & 4.352 & $<0.001$ & 7.210 \\
$\mathrm{X}_{11}$ & 8.749 & 1.351 & 6.475 & $<0.001$ & 1.293 \\
$\mathrm{X}_{12}$ & -0.183 & 0.301 & -0.607 & 0.543 & 1.601 \\
\hline
\end{tabular}

$\chi_{\mathrm{LM}}^{2}=4239.942(\mathrm{p}<0.001)$

The durian cultivation of farmers showed that the planted area is the plain area $(54.68 \%)$, sandy loam (40.51\%), using underground water $(69.87 \%)$, with enough water throughout the year (84.81\%). The diseases mostly found in durian cultivation are Pythium root rot and durian Psyllid. The farmers have mostly cultivated Monthong durian by digging plant holes (81.27\%), using $93.67 \%$ of an $8 * 8$-meter area with 18.29 trees per rai and with an average age of 14.75 years. When it comes to applying fertilizer, they use organic fertilizer (58.99\%) after the harvesting season until the sprouting phase and also use chemical fertilizer (88.61\%) (15-15-15, 16-16-16, and 17-17-17 solution). During the blooming stage, they use chemical fertilizer (90.89\%) (8-24-24 solution). During the developing stage, the farmers use chemical fertilizer through leaves (13-0-46, 10-20-30, and 15-30-15 solution) at $29.11 \%$, $24.56 \%$, and $23.80 \%$, respectively. During the fruit developing stage, they use chemical fertilizer through soil (8-24-24 and $12-12-17+2 \mathrm{Mg}$ solution) at $54.94 \%$ and $40.51 \%$, respectively. In terms of the management and operation to increase durian quality and quantity, 
this study found $97.98 \%$ of farmers pruning their trees, $62.03 \%$ of them have spared two generations of durian, 98.64\% of them pollinating flowers from 18.00 onwards, and $98.23 \%$ of them branching their trees. During the harvesting season, they all check their products by using the duration of time from blooming to the ripening of the durian. As a result, they will collect only 116.38-day-old durian. After all those previous processes, $66.84 \%$ of farmers have collectors and traders to export durian for them, and $58.99 \%$ of them accept wholesale business. Also, the farmers sell fresh durian productions, but only $29.87 \%$ were guaranteed by the GAP standard.

The factors affecting durian production in the eastern region of Thailand are presented in Table 2. The analysis of Table 2 reveals the avoidance of multicollinearity and heteroskedasticity problems by using the variance inflation factors (VIF) and Breusch-Pagan ( $\chi^{2}$ LM) heteroskedasticity tests. According to the study, the factors affecting durian production include the age of the farmers $\left(\mathrm{X}_{2}\right)$, the experience of the farmers in growing durian $\left(\mathrm{X}_{3}\right)$, the size of the workforce $\left(\mathrm{X}_{4}\right)$, the growing organic durian $\left(\mathrm{X}_{8}\right)$, the planted area of durian $\left(\mathrm{X}_{9}\right)$, the number of durian trees $\left(\mathrm{X}_{10}\right)$, and the number of durian trees per planted area $\left(\mathrm{X}_{11}\right)$. The results can be explained as follows;

When farmers are one year older, the durian production will significantly decrease by 0.479 tons at the statistical significance level of 0.05 . Thus, it can be inferred that when farmers become older, they will not know about technology changes compared to younger farmers. When the experience of farmers in growing durian increased by one year, the production would also significantly increase by 0.466 tons at the statistical significance level of 0.1 . Thus, it can be implied that experience is very important for producing quality durian, and the application of new technology in a specific area can also help. When using one additional person in the labor force, the production will significantly increase by 4.903 tons at the statistical significance level of 0.05 . Thus, it can be inferred that labor is the main factor in durian production since labor is mainly provided by people and still does not have to involve any technology to work instead of people who still do not possess the technology. This is consistent with the findings of Suriya et al. (2017) and DATEPUMEE et al. (2019), who found that farmer experience, including training attendance and agricultural knowledge, influenced productivity in case of banana and durian in Thailand as well as Suriya et al. (2017), Promchon et al. (2018), and Saisaard et al. (2021) found that increasing the number of the workforce could enhance the efficiency of production in case of banana, table grape, and rice in Thailand. Therefore, farmers with long experience in durian production will be able to produce durian well, which results in considerable labor required in the management of durian production. The farmers who produce organic durian will have fewer outcrops than the others who produce conventional (chemical) durian by around 6.154 tons at the statistical significance level of 0.05 . Thus, it can be inferred that producing organic durian without using chemical fertilizer can cause nutritional deficiencies in the short term and leads to a longer time being needed to grow. When increasing the planted area by one rai, the production will increase by 11.736 tons at the statistical significance level of 0.01 . With farmers planting one more durian tree, the production will increase by 0.376 tons at the statistical significance level of 0.01 . In addition, increasing by one more durian tree per rai, the production will increase by 8.749 tons at the statistical significance level of 0.01 . The planted area of durian, the number of durian trees, and the number of durian trees per unit of planted area affect durian production in the same direction; that is, if these factors increase, it will increase the production volume. The case of increasing planted area affecting yield is consistent with a study by Promchon et al. (2018), who found that planted area affected table grape production in Thailand. Even though the number of durian trees is very important in durian production, we still have to calculate the density of durian for a given area to receive the best outcomes. The model in Table 2 has described $98.932 \%$ of durian production in the eastern region of Thailand. On the other hand, the gender, the durian growing pattern, the GAP standard, the water resources for growing durian, and the age of the durian trees did not play any significant part in durian production.

\section{CONCLUSION AND RECOMMENDATIONS}

In recent years, farmers are interested in growing durian instead of other crops such as Para rubber, oil palm, and other fruits because the demand for durian consumption in both domestic and foreign markets has been rising, and the price of durian fruits has increased as well. For this reason, farmers have expanded their growing areas from the past with the main growing areas in the eastern 
and southern regions, but nowadays, they have expanded their growing areas throughout all regions of Thailand, resulting in a continuous increase in the amount of durian in the country. Sometimes, there are some groups of farmers grow durian which focuses on producing too large quantities that sometimes they do not pay attention to the production of quality durian including variability of climate and weather, which causes production problems such as diseases and pests in durian, and fungi in durian both before and after production. As a result, the durian tree has deteriorated, and it affects the yield, which is not as expected, as well as the quality of the durian that does not meet the market demand.

Hence, this research aims to analyze the factors affecting durian production in the eastern region of Thailand, namely Chanthaburi, Rayong, and Trad Provinces which are the area where durian production is most efficient, both the high quantity and best quality of the durian that are acceptable for export in the global market. The samples were selected by 395 farmers who cultivate durian using a simple random sampling approach. Multiple regression analysis was employed using the production function concept. Multicollinearity and autocorrelation were considered to prevent the violation of the classical linear regression model. According to the results, positive factors that affect durian production are the experience of farmers in growing durian, the size of the workforce, the planted area of durian, the number of durian trees, and the number of durian trees per unit of the planted area. In contrast, negative factors are the age of the farmers and the growing organic durian. The experience of farmers in growing durian and the size of the labor force affects the production of durian, as durian cultivation has quite a lot of production details, starting from the preparation of durian varieties, the planting process, and the maintenance of the durian, watering, pruning, fertilizing, etc. However, it is important to consider the densities of the durian trees in a given planted area appropriately because if the number of durian trees in a given area is too high, it can lead to a decrease in production efficiency and result in higher production costs. The age of farmers has a negative effect on durian production as the older farmers may not be exposed to modern production technology or adjust the production patterns to suit modern durian production. In addition, when comparing organic durian production with conventional durian production, organic durian production was found to be less efficient than conventional durian production.

When it comes to the recommendations, farmers should be encouraged and provided training programs on increasing the efficiency of durian production to enhancing their knowledge and exchange experiences with successful durian growers as the increased experience of farmers will result in higher efficiency for durian production. There should also be research and development of durian production practices to reduce the workforce by using appropriate technology. Since durian production requires a lot of labor to take care of durian production at every step, using technology to replace labor is necessary to reduce production costs and increase production efficiency. Moreover, the government sector and related stakeholders should support fundamental knowledge of technology to improve the production process and improve durian production to respond to market demands, as well as managing the production process to receive quality products throughout the supply chain, following agricultural guidelines, quality controls and shipping from the plantations to the markets to increase reliability for domestic and international consumers. For the limitations, this study suggests that panel data analysis using Just and Pope's stochastic production should be considered to estimate the effect of climatic factors such as temperature series and precipitation on agricultural output and its variability as studies of Haile et al. (2017), Attiaoui and Boufateh (2019), and Sarker et al. (2017) including non-climatic factors such as agricultural land use, workforce, capital variables in order to find out suitable analytical solutions to support policy planning at both the micro and macro levels as well as to enhance the efficiency of agricultural production of the country.

\section{REFERENCES}

Attiaoui, I. and T. Boufateh. 2019. Impacts of climate change on cereal farming in Tunisia: a panel ARDL-PMG approach. Environmental Science and Pollution Research, 26: 13334-45.

Datepumee, N., P. Sukprasert, C. Jatuporn and S. Thongkaew. 2019. factors affecting the production of export quality durians by farmers in chanthaburi province, thailand. Journal of Sustainability Science and Management, 14: 94105. 
Department of Agricultural Extension. 2016. Online agricultural production information system. [Online] Available at: $<$ https://production.doae.go.th/site/login.

Durian Harvests. 2021. Global durian trade \& demand. [Online] Available at: <https://www. durianharvests.com/global-trade/> [Accessed 5 June 2021].

Guntukula, R. and P. Goyari. 2020. Climate Change Effects on the Crop Yield and Its Variability in Telangana, India. Studies in Microeconomics, 8: 119-48.

Haile, M. G., T. Wossen, K. Tesfaye and J. von Braun. 2017. Impact of Climate Change, Weather Extremes, and Price Risk on Global Food Supply. Economics of Disasters and Climate Change, 1: 5575.

Hassan, I., M. B. Chattha, T. H. Chattha and M. A. Ali. 2010. Factors affecting wheat yield: a case study of mixed cropping zone of Punjab. J. Agric. Res, 48: 403.

Ministry of Commerce. 2020a. The major export products of Thailand according to the world export structure. [Online] Available at: <http://tradereport.moc.go.th/TradeThai.aspx>

[Accessed 16 March 2021].

Ministry of Commerce. 2020b. Thailand's top 15 export markets by country: Fresh Durian. [Online] Available at: <http://tradereport.moc.go.th/TradeThai.aspx> [Accessed 16 March 2021].

Office of Agricultural Economics. 2020a. Agricultural economics information classified by commodity in 2019. Center of Agricultural Information, Office of Agricultural Economics. Bangkok, Thailand.

Office of Agricultural Economics. 2020b. Agricultural statistics of Thailand 2019. Center of Agricultural Information, Office of Agricultural Economics. Bangkok, Thailand.

Office of Agricultural Economics. 2020c. Thailand foreign agricultural trade statistics 2019. Center of Agricultural Information, Office of Agricultural Economics. Bangkok, Thailand. Place Published.

Pipitpukdee, S., W. Attavanich and S. Bejranonda. 2020. Impact of Climate Change on Land Use, Yield and Production of Cassava in Thailand. Agriculture, 10: 402.

Promchon, P., P. Sukprasert, C. Jatuporn, K.
Kittiwatsopon and S. Pattanakiat. 2018. Factors affecting table grape production: Introductory analysis. Siam Academic Review, 19: 1-13.

Rueangrit, P., C. Jatuporn, V. Suvanvihok and A. Wanaset. 2020. Forecasting Production and Export of Thailand's Durian Fruit: An Empirical Study using the Box-Jenkins Approach. Humanities and Social Sciences Letters, 8: 430-37.

Saisaard, P., C. Jatuporn and M. Toyama. 2021. Factors affecting Sangyod rice production of farmers in Mueang district, Phattalung province. , 4(1): 2537. Journal of Multidisciplinary in Humanities and Social Sciences, 4: 25-37.

Sarkar, M. S. K., R. A. Begum and J. J. Pereira. 2020. Impacts of climate change on oil palm production in Malaysia. Environmental Science and Pollution Research, 27: 9760-70.

Sarker, M. A. R., K. Alam and J. Gow. 2017. Performance of rain-fed Aman rice yield in Bangladesh in the presence of climate change. Renewable agriculture and food systems, 34: 304-12.

Shayanmehr, S., S. Rastegari Henneberry, M. Sabouhi Sabouni and N. Shahnoushi Foroushani. 2020. Drought, Climate Change, and Dryland Wheat Yield Response: An Econometric Approach. International Journal of Environmental Research and Public Health, 17: 5264.

Somsri, T. 2008. Thai durian and breeding: A case study of Chanthaburi 1, Chanthaburi 2, Chanthaburi 3. Expert Office, Department of Agriculture. Bangkok, Thailand.

Suriya, O., C. Jatuporn, P. Sukprasert and S. Pattanakiat. 2017. Factors affecting Cavendish banana production of farmers in Nong Suea district, Pathum Thani Province. Panyapiwat Journal, 9: 208-18.

Thongkaew, S. 2018. The appropriate systematic model for sustainable development of durian farmers in the eastern region of Thailand. (Unpublished doctoral dissertation). Kasetsart University. Bangkok, Thailand.

Thongkaew, S., P. Sukprasert and C. Jatuporn. 2017. Factors affecting decision making for purchasing durian in the eastern region of Thailand: a case study of entrepreneurs. Journal of Agricultural Research and Extension, 34: 63-72.

Tun, Y. and H.-J. Kang. 2015. An Analysis on the Factors Affecting Rice Production Efficiency in Myanmar. 
East Asian Economic Review, 19: 167-88.

Yamane, T. 1973. Statistics: An introduction analysis. Harper \& Row.

Zhang, Q., W. Dong, C. Wen and T. Li. 2020. Study on factors affecting corn yield based on the CobbDouglas production function. Agricultural Water
Management, 228: 105869.

Zulu, N. S., M. Sibanda and B. S. Tlali. 2019. Factors Affecting Sugarcane Production by Small-Scale Growers in Ndwedwe Local Unicipality, South Africa. Agriculture, 9: 170.

Publisher's note: EScience Press remains neutral with regard to jurisdictional claims in published maps and institutional affiliations.

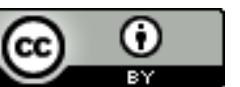

Open Access This article is licensed under a Creative Commons Attribution 4.0 International License, which permits use, sharing, adaptation, distribution and reproduction in any medium or format, as long as you give appropriate credit to the original author(s) and the source, provide a link to the Creative Commons license and indicate if changes were made. The images or other third-party material in this article are included in the article's Creative Commons license, unless indicated otherwise in a credit line to the material. If material is not included in the article's Creative Commons license and your intended use is not permitted by statutory regulation or exceeds the permitted use, you will need to obtain permission directly from the copyright holder. To view a copy of this license, visit http://creativecommons.org/licenses/by/4.0/. 